\title{
Histone Acetyltransferase KAT6B
}

National Cancer Institute

\section{Source}

National Cancer Institute. Histone Acetyltransferase KAT6B. NCI Thesaurus. Code C71450.

Histone acetyltransferase KAT6B (2073 aa, $231 \mathrm{kDa}$ ) is encoded by the human KAT6B gene. This protein plays a role in both histone acetylation and the regulation of transcription. 